subsequent treatment was mainly directed to straightening the limb to the full extent, and whicb, I doubt not, will eventually be attained. Meanwhile, an opportunity offered of sending the patient to England. He was accordingly invalided, and em. barked at Hong.Kong on the 3rd of August.

Hong-Kong, 1862.

REPORT OF A

\section{CASE OF HEPATIC ABSCESS BURSTING EXTERNALLY, AND BEING CONNECTED WITH THE COLON.}

By R. DOMENICHETTT, M.D., SERGEON, 75TH REGIMENT.

Private John $R-$, 75th Regiment, aged twenty-three, tall, and of slight conformation, served in India three years, during which period he had frequent attacks of fever and dysentery. In December, 1S61, he was first treated for acute dysentery, when stationed in Calcutta. Tpecacuanha in large doses (twenty to forty grajns) was prešcribed, according to the method adrocated by Dr. Scott Docker in 1858, which has been found so beneficial and effective in this formidable dis. order. In this instance the acute symptoms were speedily overcome, as, by reference to the register, I find that he was admitted into hospital on the 17 th December, and discharged on the $22 \mathrm{nd}$ of the same month; but two relapses are reported to have occurred, as he was subsequently in hospital with the same complaint for thirty-nine days.

He embarked for England with his regiment on the 24th of February, 1862, and appears to have suffered at times on the voyage. He was able to perform the duties of hospital orderly on his arrival at Plymouth in $J$ une, but was compelled to report himself sick on the 23rd of A ugust, on account of pain in the bepatic region, accompanied with dysentery.

On the 27th of September, Assistant-Surgeon Millar, who had charge of the patient, first noticed a swelling in the right side, corresponding with the two lower false ribs behind, characterized by evident fluctuation and great pain ; considerable constitutional disturbance was also present. The urine was strongly acid, sp. gr. 1016, with copious deposits of lithates. Rigors alternating with profuse perspirations, and all the symptoms of hectic, set in. A remarkable feature was also noticed : percussion elicited a resonant sound in the vicinity of the abscess, indicating the presence of air, which was a source of some difficulty in the diagnosis. It was presumed that the abscess had some comnexion wilh the intestines, through which alone the ingress of air could be nccounted for. The question now arose, whether it was desirahle to evacuate its content with a trocar, or to leave it to burst spontaneously. The presence of air in the tumour was regarded as a contra-indication to the operation and on Oct. 19 th, the abscess, which had attained the size of an orange, gave way, and about half a pint of thin ill conditioned-looking pus mixed with blood was discharged, followed by great relief to the patient. His strength was supported by stimulants, the discharge continuing unabated and in the course of two or three days an extensive slough of the integuments in the vicinity of the abscess took place, resulting in an aperture of an oval shape, the long diameter of which measured three inches, and through it could be seen the free margin of the liver and folds of intestine, all presenting a black and sloughy condition. The discharges from the bowel were also frequent, and resembled in appearance what came from the abscess. He lingered in this state until the $26 \mathrm{th}$ of October, when he died.

The autopsy, twelve hours after death, confirmed the diagnosis, as a connexion was found to exist between the intes tines and the walls of a large abscess occupying the cavity between the abdominal parietes and the ascending colon, connected superiorly with the base of the right lobe of the liver which was pervaded by a large abscess running into that just described. The structure of the liver was also dotted with secondary abscesses, and varying in size. The liver weighed $4 \mathrm{lbs} .9 \mathrm{oz}$. The contents of the thorax were healthy, with the exception that some pleuritic adhesions were found corresponding with the lower lobe of the right lung, the structure of which, from its contiguity to the diseased liver, was congested. The kidneys were healthy, and weighed between five and six ounces.
Stomach and intestines: Some congestion existed at the cardiac extremity of the stomach. The rectum and colon were pale and thickened, also studded at intervals with large ulcers of long standing. The ascending colon, from its proximity to the abscess, had its walls much thickened, and the opening of communication was of considerable size. Small intestines : There were a few patches of congestion; but they presented no other appearance of disease.

Under the microscope the lobules throughout the greater portion of the liver were seen to be in a state of fatty degeneration, these in many instances having lost their normal appearance, and consisting entirely of faí cells. This was particularly noticed in a section taken from the neighbourhood of one of the secondary abscesses, in which the gradual transition from the healthy lobule to a state of fatty degeneration was very apparen. Devonport, 1863.

\section{d arrut}

\section{OF THE PRACTICE OF}

\section{MEDICINE AND SURGERY IN THE}

\section{HOSPITALS OF LONDON.}

Nulla est alia pro certo noscendi via, nisi quam plurimas et morborum et dissectionum historias, tam aliorum proprias, collectas habere et inter se com parare.-Morgagn. De Sed. et Caus. Morb., lib. 14. Procnium.

\section{KING'S COLLEGE HOSPITAL.}

DEEP-SEATED TUMOUR OF THE THIGH ; OPERATION FOR ITS REMOVAL; SUDDEN DEATYY THIRTY HOURS AFTERWARDS

(Under the care of Mr. Henry Smith.)

In going over the details of the following case, - the notes of which were taken by Mr. Ferris, the dresser of the patient,the question will arise as to the cause of death. If it had been an operation of ovariotomy, we should have unhesitatingly pro. nounced it the result of shock; but in the present instance it can hardly be so considered. We incline to the opinion that chloroform had much to do with it, from the manner in which the symptoms presented themselves during the last hours of life, and remembering at the same time that the patient was fully under its influence during a necessarily somewhat protracted operation, at which but very little blood was lost. Nevertheless, she appeared to have recovered from the immediate effects of the chloroform.

B. S-, aged thirteen, a very tall girl for her age, pallid, and rather thin, was admitted on the 17 th of January, with tumour on the upper part of the left thigh. Upwards of four years ago she fell upon the front part of the thigh, and experienced so much pain in the part that she was compelled to keep to her bed for six weeks. Soon afterwards a swelling appeared at the seat of the injury, and this gradually increased in size. In January of last year she was seen by an eminent surgeon, who proposed to perform an operation, and went to the house of the patient prepared to do it; but, after a careful examination, it was deferred. Subsequently she saw Mr. Ferrusson and Mr. Henry Smith, both of whom considered that the tumonr was movable, and that if it increased or became painful it should be taken away. This was about six months prior to the above date; and subsequently the tumour had both increased in size and become more painfal, so that the girl was admitted for the purpose of having it removed. On examination, there was a great fulness of the upper part of the thigh, and the superficial veins were much enlarged. There was a distinct, hard, movable tumour, extending from about three inches below the anterior spinous process to the commencement of the lower third of the thigh, measuring about five inches in length and three and a half or four inches in breadth. Its upper and lower margins were pretty well defined; but its lateral edge seemed to glide into the surronnding parts. When the thigh was exteniled the tumour was neither defined nor movable; but when the limb was flexed, and the extensor muscles relaxed, the limited and movable character of the 